\title{
Optimization of operational techniques in waste management case study: Lhokseumawe City
}

\author{
Ade Widya Isharyati ${ }^{1,}$, Agus Prasetya $^{2}$, and Rochim Bakti Cahyono ${ }^{2}$ \\ ${ }^{1}$ Master of System Engineering, Universitas Gadjah Mada, Indonesia \\ ${ }^{2}$ Department of Chemical Engineering, Universitas Gadjah Mada, Indonesia
}

\begin{abstract}
The high volume of waste that is not followed by properly waste management method, makes the waste management in Lhokseumawe not optimal. This problem is shown by the level of waste service is only about $38 \%$, while the waste that is not transported will be cumulative in any places. This is showed that the level of waste service is below of the minimum service standard that is $60 \%-90 \%$. It is necessary to improve the waste management, especially in the utilization of waste to reduce the waste and landfill load. This research aims to evaluated and analysis of waste management in Lhokseumawe by two waste reduction scenarios, that are waste bank scenario and recycle scenario. The method that were used in this research are material balance analysis, lifetime of landfill, and cost analysis. The result showed that waste reduction by scenario 1 and scenario 2 can reduce of waste in landfill about $49.8 \%$ and $51.02 \%$. The lifetime of landfill by the waste reduction can be used for 28 years from the lifetime 18 years. Investment cost estimated that required in scenario 1 and scenario 2 are smaller than the investment cost of existing, respectively IDR746,646,860, IDR755,530,822 and IDR1,202,644,444.
\end{abstract}

\section{Introduction}

Lhokseumawe city is one of the cities located in North Aceh, Nanggroe Aceh Darussalam with the population in 2017 is 195,186 people [1]. The population will increase every year with the population growth rate of Lhokseumawe is $1.9 \%$ [1]. Increasing population will affect of waste generation in a city. Waste generation in Lhokseumawe in 2017 is $2.871 \mathrm{~L} /$ person/day [2]. The amount of waste generation will affect the waste management systems, whereby waste management system in Lhokseumawe is end of pipe method, without sorting and waste process. Based on Government Regulation No. 18/2008 about Waste Management, it is necessary to change the conventional waste management paradigm into nonconventional waste management by optimization of waste management and utilization [3]. In waste management, there are five aspects that need to be considered, one of which is the operational technique aspects. Operational technique aspects include waste sources, waste generation, and composition; facilities and infrastructure; and waste treatment. Waste treatment is one of the requirements in waste management to reduce waste level in landfill (TPA) [4]. This study aims to optimize the technique aspects of waste management in Lhokseumawe City, especially in the utilization and waste treatment by two alternative scenarios, namely waste bank scenario and recycling scenario.

\subsection{Waste management existing}

The current waste management in Lhokseumawe City uses end of pipe paradigm without sorting process and waste treatment. Total of waste quantities in Lhokseumawe in 2017 is 560,379 liter/day. Mostly, the waste management is conducted by $7 \%$ burned, $5 \%$ dumped to roadside or river, and $3 \%$ waste is dumped in backyard. Transportation of waste from TPS to TPA is only about $38 \%$, due to the limited of facilities. The scheme of waste managements in Lhokseumawe can be showed as Figure 1.

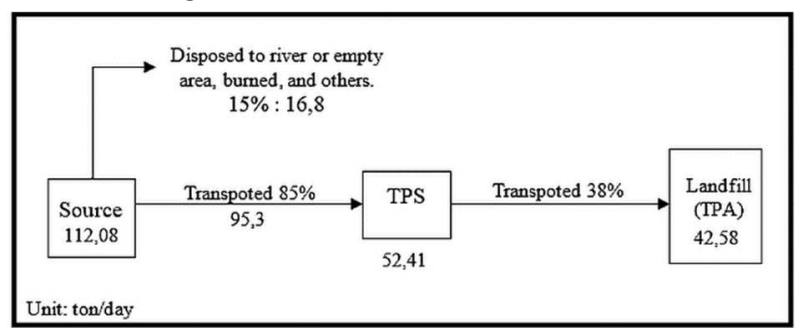

Fig. 1. Existing waste management.

\footnotetext{
* Corresponding author: ade.w@mail.ugm.ac.id
} 


\section{Method}

\subsection{Waste generation}

The data of waste generation are obtained from Dinas Lingkungan Hidup Kota Lhokseumawe (DLH) according to SNI 19-3964-1994. The waste generation of Lhokseumawe in 2016 is $2.871 \mathrm{~L} /$ person/day or 560,379 L/day.

\subsection{Waste composition}

Based on data report of DLH, composition of waste in Lhokseumawe is dominated by organic about $70 \%-80 \%$ such as food scraps, leaves, fruit, and others. While the inorganic waste such as plastics, metals, construction materials, glass and others, as shown in Figure 2.

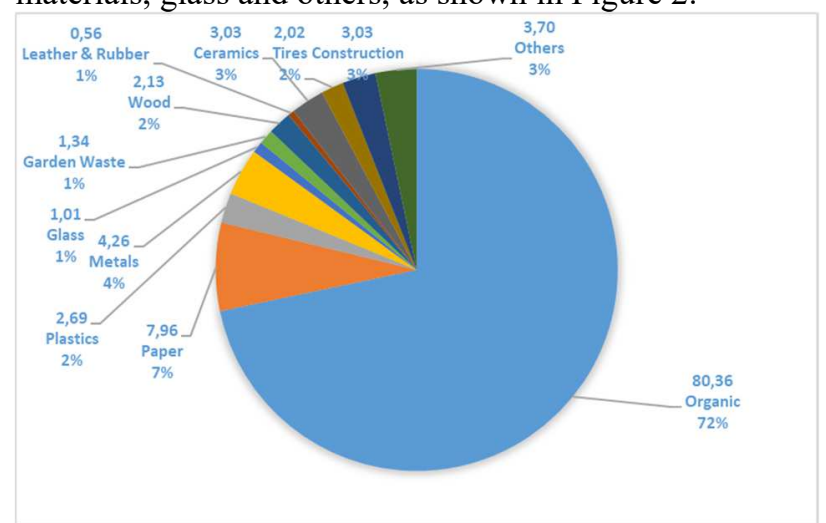

Fig. 2. Waste composition.

The waste composition has potential to be recycled, so that not only can reduce waste transported to landfill and extend the lifetime of landfill but also will reduce the operational cost of waste transported.

\subsection{Material balance analysis}

This method is used to find out the detail of material balance in each stream of waste source of generation, can be formulated in the equation.

Total Waste Balance:

$$
\Sigma(\text { Mass of Waste Out })=\Sigma(\text { Mass of Waste In })
$$

Component Waste Balance:

$$
\sum\left(M_{\text {out }} X\right)=\sum\left(M_{\text {in }} X\right)-\sum\left(M_{\text {dis }} X\right)+\sum\left(M_{\text {gen }} X\right)
$$

Where:

$\sum\left(M_{\text {out }} X\right)$ : Mass of waste out of component X

$\sum\left(M_{i n} X\right)$ : Mass of waste in of component $\mathrm{X}$

$\sum\left(M_{d i s} X\right)$ : Mass of waste disapeared of component X

$\sum\left(M_{\text {gen }} X\right)$ : Mass of waste generated of component X

$X$ : Component considered, can be plastic, organic, etc.

\subsection{Waste bank scenario (Scenario 1)}

The scheme of waste management in this scenario, inorganic waste is carried to waste bank to be recycled.
An inorganic waste that can not be recycled in waste bank, then was carried to waste shelter (TPS 3R) for further recycled, while organic waste is used for composting. Inorganic and organic waste that can not be recycled is carried to landfill as shown in Figure 3.

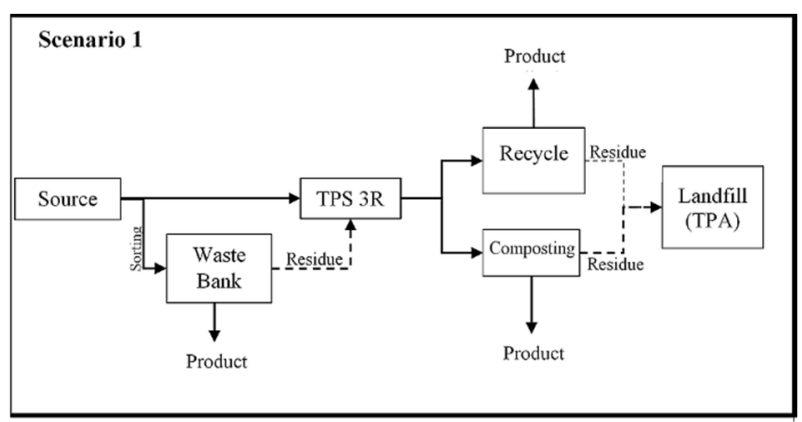

Fig. 3. Scheme of waste management scenario 1.

\subsection{Recycling scenario (Scenario 2)}

The scheme of waste management in this scenario same as scenario 1, but inorganic waste such as tires and plastics that can not recycled will be processed by pyrolisis to synthetic oil. Furthermore, inorganic and organic waste that can not be recycled then carried to landfill. In the landfill will built biogas installations by methane gas

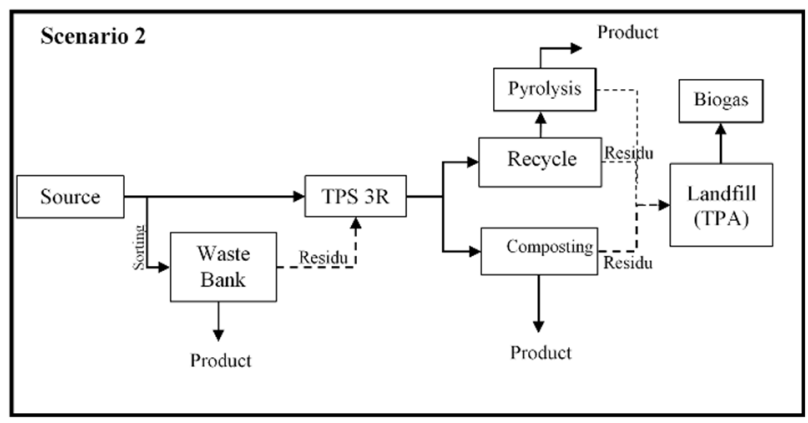

utilization from waste dump as shown in Figure 4.

Fig. 4. Scheme of waste management scenario 2 .

\subsection{Cost analysis}

Cost analysis is used to find out the required cost of waste management in each scenario including investment cost (fixed cost), operational cost, income and profit. This analysis can be formulated in equation [5]:

$$
\begin{aligned}
& \text { Investment cost }=\text { Initial cost }+ \text { Equipment cost } \\
& \text { Operational cost }=\text { Variable cost }+ \text { Fixed cost } \\
& \text { Income }=\text { Amount of Product } \mathrm{kg} / \text { day }+ \text { Price } / \mathrm{kg} \\
& \text { Profit }=\text { Income }- \text { Operational Cost }
\end{aligned}
$$

Investment and operational cost are consists of investment and operational costs of landfill, waste transportation cost, and investment of waste bank and TPS 3R. Income earned are the proceeds from sales of waste products assumed that $100 \%$ sold each day. 


\section{Discussion}

\subsection{Waste composition}

The waste composition in Lhokseuawe is dominated by organic waste of $71.1 \%$, paper of $7.1 \%$, plastics of 2.4 $\%$, metal of $2.1 \%$ and glass of $1.9 \%$. The potential for recycling of inorganic waste based on Tchobanoglous, 1993 , the percentage of recycled paper is $40 \%$, plastic is $50 \%$, metal is $85 \%$ and glass is $65 \%$ [6]. The potential of organic waste is about $30 \%$ to $40 \%$ [5]. By the percentage of potential waste recycling can reduce the amount of waste composition to landfill. Recycling of inorganic waste can be recycled in various ways such as recycling waste into craft products, raw material products and inorganic waste recycling using technology. The simplest recycling organic waste is to use it as a compost material. In addition to reducing waste, recycling activities can also provide a high potential role for the community that involves the workers. Participation of community is also an important aspect of solid waste management [5].

\subsection{Waste management existing}

The waste management scheme in this scenario is waste from source is managed by society about $15 \%$ conducted by burned and dumped in empty area or river. The waste transported to landfill is only about $38 \%$ equal 42.6 ton/day of waste total. While the remaining of waste that is not transported will be acumulated in any places about 52.41 ton/day.

The lifetime of landfill in this scheme is about 18 years. The investment and operational cost are only consists of investment and operational of landfill and transportation facilities. Total investment and operational cost in this scheme are IDR1,202,644,444 and IDR2,633,618,444. There is no income and profit earned in this scheme because there is no waste product can be sold.

\subsection{Scenario 1}

The waste management scheme in this scenario is conducted by inorganic waste from the source is carried to the waste bank to be used as a craft. The remaining of inorganic waste that can not be recycled in the waste bank is then carried to TPS $3 \mathrm{R}$. In TPS $3 \mathrm{R}$ inorganic waste is recycled into raw material products, while organic waste is used as raw material of compost. The remaining waste that is not recyclable will be carried to the landfill. The analysis of material balance in this scenario is shown in Table 1.

Table 1. Material balance analysis scenario 1 .

\begin{tabular}{|l|r|r|r|r|}
\hline \multirow{2}{*}{ Component } & \multicolumn{4}{|c|}{ Waste reduction (ton/day) } \\
\cline { 2 - 5 } & Source & $\begin{array}{c}\text { Waste } \\
\text { bank }\end{array}$ & TPS 3R & Landfill \\
\hline Organic & 80.36 & - & 12.83 & 36.03 \\
\hline Paper & 7.96 & 3.18 & 1.91 & 2.86 \\
\hline Plastics & 2.69 & 1.34 & 0.67 & 0.67 \\
\hline Metals & 2.35 & 2.00 & 0.30 & 0.05 \\
\hline Glass & 2.13 & 1.38 & 0.71 & 0.04 \\
\hline Garden Waste & 1.68 & - & - & 1.68 \\
\hline Wood & 2.58 & - & - & 2.58 \\
\hline Leather \& rubber & 0.56 & - & - & 0.56 \\
\hline Ceramics & 3.03 & - & 2.87 & 0.15 \\
\hline Tires & 2.02 & - & - & 2.02 \\
\hline Construction & 3.03 & - & - & 3.03 \\
\hline Others & 3.70 & - & - & 3.70 \\
\hline Total & 112.08 & 7.91 & 19.29 & 53.37 \\
\hline
\end{tabular}

Based on the analysis of waste material balance, the percentage of waste that can be reduced from each stream as shown in Figure 5.

The percentage of inorganic waste that can be reduced by waste bank consists of paper, plastic, metal and glass is $7.06 \%$ or 7.91 ton/day of total inorganic waste $13.5 \%$. While the percentage of inorganic waste that can be

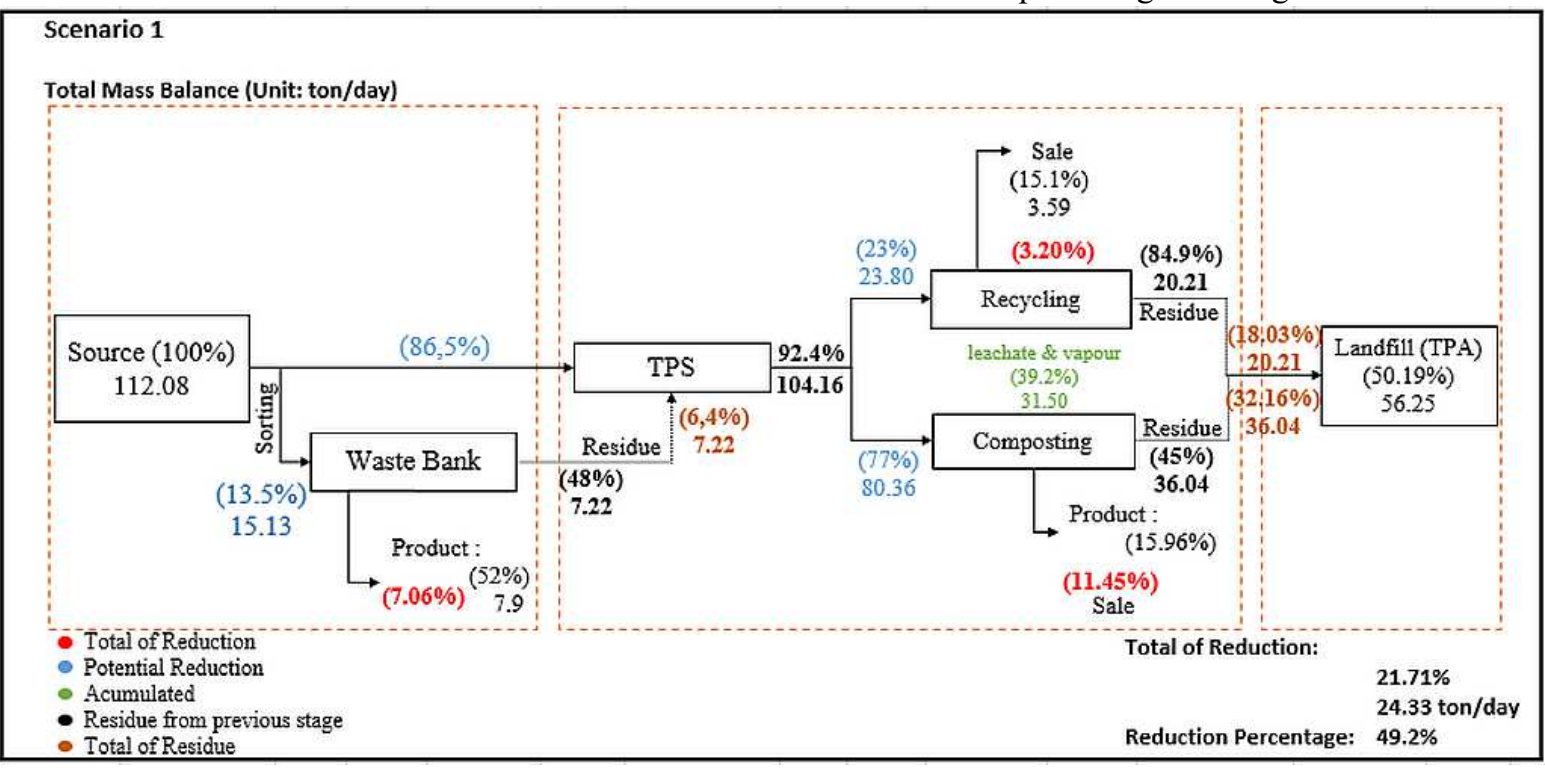

Fig. 5. Material balance analysis of scenario 1 . 
reduced by recycling in TPS $3 \mathrm{R}$ is $5.77 \%$ or 6.46 ton/day.

The organic waste that can be compost products is $11.44 \%$ or 12.82 ton/day of total organic waste 80.36 ton/day.Total waste that can be reduced by this scenario is about $21.65 \%$ or 24.27 ton/day. The total remaining waste that can not be recycled is 56.26 ton/day will disposed to landfill. If the waste that transported to landfill is only $38 \%$ or 21.38 ton/day, it can extended the lifetime of landfill about 27 years and reduce the investment and operational cost.

The investment cost that required in this scenario is IDR746,646,860, operational cost is IDR3,036,825,120. The investment and operational cost are cost of investment and operational of landfill, transportation of waste, waste bank and TPS 3R. In this scenario, the total investment is smaller than investment of existing. This is due to the longer lifetime of landfill, so that investment cost for landfill becomes smaller each year. Whereas the operational cost is greater than existing, this is because there are additional operational costs for waste bank and TPS 3R that does not exist in existing management. The profits that earned is IDR192,997,400 each year, is a profit proceed from selling of waste products.

\subsection{Scenario 2}

The waste management scheme in this scenario is same as scenario 1 consisting of waste bank, recycling in TPS 3R. But in this scenario is will be added pyrolisis process to process non recyclable inorganic waste such as plastics and tires in TPS $3 R$, and biogas installation in landfill. The analysis of material balance in this scenario is shown in Table 2.
Table 2. Material balance analysis scenario 2.

\begin{tabular}{|l|r|r|r|r|}
\hline \multirow{2}{*}{ Component } & \multicolumn{4}{|c|}{ Waste Reduction (ton/day) } \\
\cline { 2 - 5 } & Source & $\begin{array}{c}\text { Waste } \\
\text { bank }\end{array}$ & \multicolumn{1}{|c|}{ TPS 3R } & Landfill \\
\hline Organic & 80.36 & - & 12.83 & 36.03 \\
\hline Paper & 7.96 & 3.18 & 1.91 & 2.86 \\
\hline Plastics & 2.69 & 1.34 & 1.10 & 0.01 \\
\hline Metals & 2.35 & 2.00 & 0.30 & 0.05 \\
\hline Glass & 2.13 & 1.38 & 0.71 & 0.04 \\
\hline Garden Waste & 1.68 & - & - & 1.68 \\
\hline Wood & 2.58 & - & - & 2.58 \\
\hline Leather \& Rubber & 0.56 & - & - & 0.56 \\
\hline Ceramics & 3.03 & - & 2.87 & 0.15 \\
\hline Tires & 2.02 & - & 0.36 & 1.34 \\
\hline Construction & 3.03 & - & - & 3.03 \\
\hline Others & 3.70 & - & - & 3.70 \\
\hline Total & 112.08 & 7.91 & 20.08 & 52.03 \\
\hline
\end{tabular}

The percentage of inorganic waste that can be reduced by waste bank is $7.06 \%$ or 7.91 ton/day of total inorganic waste $13.5 \%$. While the percentage of inorganic waste that can be reduced by recycling in TPS $3 \mathrm{R}$ is $6.49 \%$ or 7.28 ton/day. The organic waste that can be compost products is $11.44 \%$ or 12.82 ton/day of total organic waste 80.36 ton/day. Total waste that can be reduced by this scenario is about $25.1 \%$ or 28.02 ton/day. The total remaining waste that can not be recycled is 54.90 ton/day will disposed to landfill. While total of waste reduction percentage in this scenario is $51.02 \%$.

Based on the analysis of waste material balance, the percentage of waste that can be reduced from each stream as shown in Figure 6.

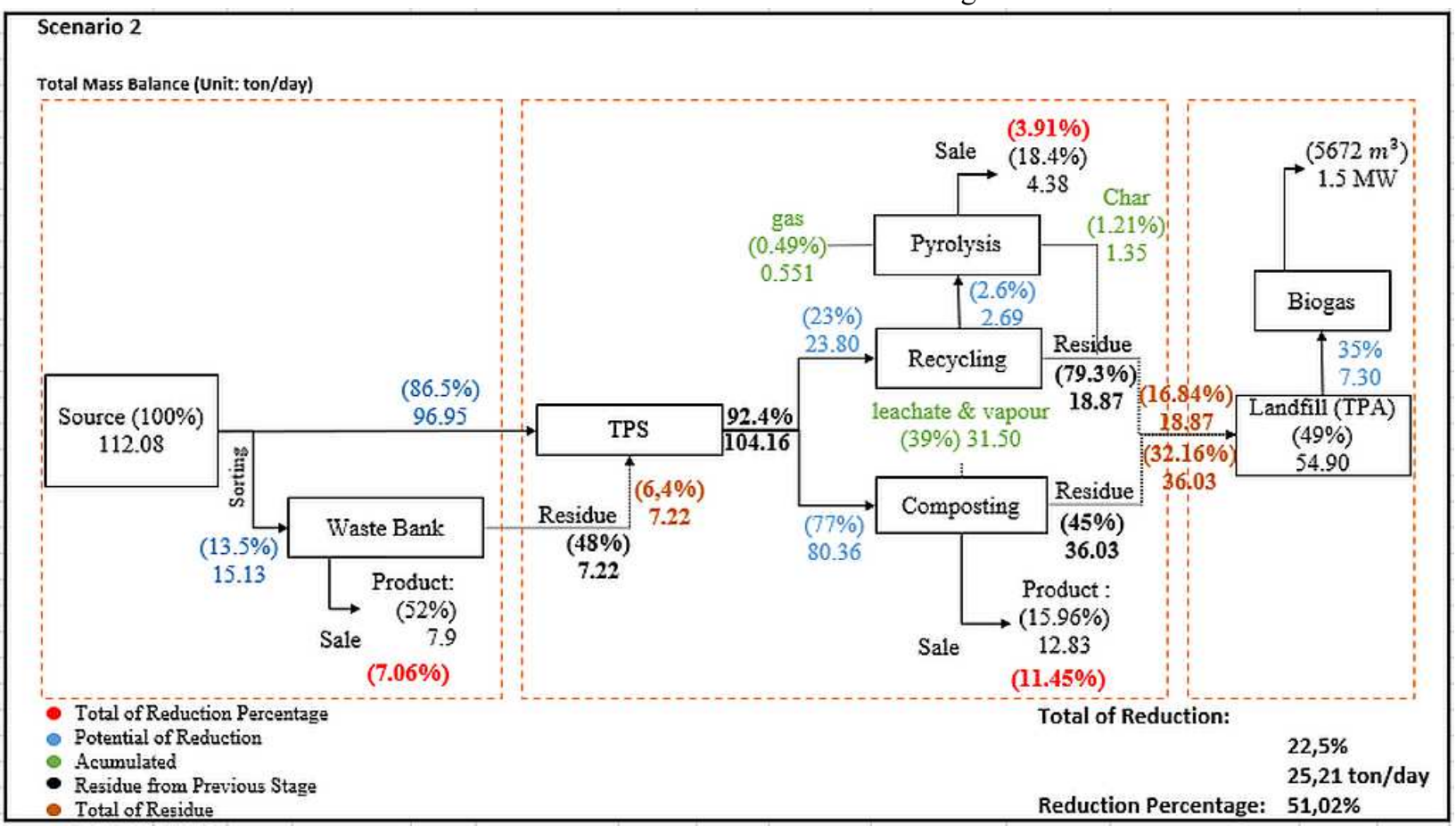

Fig. 6. Material balance analysis of scenario 2 . 
Further, the utilization of methane gas from waste level to be utilized as a replacement electrical energy in the landfill area. Potential of biogas generated from waste level is about $35 \%$ [7]. Total waste level is 54.90 tons, that can be potentially produce biogas only about 7.3 tons. The methane gas $\left(\mathrm{CH}_{4}\right)$ content in biogas is $50 \%$, so the volume of methane gas produced is $5,672.23 \mathrm{~m}^{3}$, equivalent to $1.5 \mathrm{MW}$ energy.

If the waste that transported to landfill is only $38 \%$ or 20.86 ton/day, it can extended the lifetime of landfill about 28 years and reduce the investment and operational cost. The investment and operational cost that required in this scenario are greater than the investment costs in scenario 1, that are IDR755,530,822 and operational cost IDR3,272,190,559. The investment and operational cost are greater than scenario 1 due to there is additional investment and operational cost for pyrolysis process and intallations of methane gas. The profit in this scenario is greater than scenario 1 is IDR242,344,067.

The summary of comparison waste management existing between two scenarios is shown in Table 3 .

Table 3. Comparison of scenarios.

\begin{tabular}{|l|r|r|r|}
\hline \multicolumn{1}{|c|}{ Variables } & Existing & Scenario 1 & Scenario 2 \\
\hline $\begin{array}{l}\text { Waste to } \\
\text { Landfill } \\
\text { ton/day) }\end{array}$ & 42.58 & 20.28 & 19.76 \\
\hline $\begin{array}{l}\text { Percentage of } \\
\text { Waste } \\
\text { Reduction (\%) }\end{array}$ & - & 49.8 & 51.02 \\
\hline $\begin{array}{l}\text { Lifetime of } \\
\text { Landfill (year) }\end{array}$ & 18 & 27 & 28 \\
\hline
\end{tabular}

Table 3. continued

\begin{tabular}{|l|r|r|r|}
\hline \multicolumn{1}{|c|}{ Variables } & Existing & Scenario 1 & Scenario 2 \\
\hline $\begin{array}{l}\text { Investment Cost } \\
\text { (IDR) }\end{array}$ & $1,202,644,44$ & $746,646,860$ & $755,530,822$ \\
\hline $\begin{array}{l}\text { Operational } \\
\text { Cost (IDR) }\end{array}$ & $2,633,618,44$ & $3,036,825,12$ & $3,269,941,88$ \\
\hline Revenue (IDR) & 4 & 0 & 2 \\
\hline Profit (IDR) & - & $3,229,822,52$ & $3,514,534,62$ \\
& $2,633,618,44$ & $192,997,400$ & $242,344,067$ \\
\hline & - & & 6 \\
\hline
\end{tabular}

\section{Conclusion}

Waste management system can be optimized on operational technical aspect by waste utilization that can reduce of waste. Waste utilization by recycling can reduce waste disposed to landfill. The percentage of waste reduction in scenario 1 by waste bank and recycling is $49.8 \%$ and waste reduction in scenario 2 by waste bank, recycling, and pyrolysis is $51.02 \%$. By percentage of waste reduction can extend the lifetime of landfill up to 28 years. Total investment costs that required for recycling in scenario 1 is IDR746,646,860 and scenario 2 is IDR755,530,822. Based on results the analysis, scenario 2 is more optimal alternative that can be implemented for waste management compared to scenario 1 and waste management existing by waste reduction and disposed to landfill is 20.86 ton/day, and more profitable.

\section{References}

1. Central Bureau of Statistics of Lhokseumawe City. Lhokseumawe in Figures (2017)

2. Directorate of Environmental Sanitation Development of the Directorate General of Human Settlements of the Ministry of Public Works. Facilitation Report on Planning of Technical Management of Waste Management (PTMP) of Lhokseumawe City (2016)

3. Government Regulation Number 18/2008 on Waste Management. House of Representatives of Republic Indonesia and President of Republic Indonesia. Jakarta (2008)

4. Damanhuri, E., Padmi. Diktat Lecture TI-3104 Waste Management. Institut Teknologi Bandung (ITB): Bandung (2010)

5. Tchobanoglous. Integrated Solid Waste Management Engineering Principles and Management Issues. New York: Mc Graw Hill Inc (1993)

6. Damanhuri, Padmi. Diktat Waste Management. Environmental Engineering Institute of Technology Bandung (ITB): Bandung (2004)

7. Miradian. Study on Utilization Potential Gas (Biogas) Sanitary Landfill Banyuurip As an Alternative Energy Source of Gas Medium Btu and Power Plant (Study Case of Magelang City). Faculty of Engineering University of Diponegoro, Semarang. (2010) 